\title{
The Nexus between Social Capital and Reintegration of Ex-combatants: A Case for Sierra Leone
}

Jonah Leff *

\begin{abstract}
Following the end of the cold war, the international community shifted its attention from duelling ideological warfare to the many intra-state, or internal armed conflicts occurring globally. In response, the United Nations, along with a wide array of aid agencies, have invested greater and greater time and resources in post-conflict environments. When peace is reached after conflict, economic and social conditions are not conducive for ex-combatants to reintegrate on their own. Programmes that address ex-combatants as well as broader post-conflict recovery are essential. Disarmament, Demobilisation, and Reintegration (DDR) is one such programme that has received widespread attention. Policy analysts have debated the factors that contribute to a successful DDR programme.
\end{abstract}

\footnotetext{
* Jonah Leff is a consultant for the Geneva-based Small Arms Survey, where he has focused on issues ranging from African security to the impact of small arms and light weapons on children. In 2007, he received a Masters in Public Administration in International Management from the Monterey Institute of International Studies.
} 
This study examines reintegration, the final phase of DDR, arguing that in order to achieve successful reintegration of ex-combatants, a communityfocused approach that generates social capital must be implemented. Using a comprehensive literature review of social capital and community-based reintegration and a thorough case study from Sierra Leone, this paper will demonstrate the relationship between social capital and reintegration.

\section{Introduction}

Since the end of the cold war, the international community has shifted its focus from what for decades was characterised by duelling ideological warfare to the many masked internal armed conflicts taking place throughout the world. In doing so, international organisations and States have placed postconflict peacekeeping and reconstruction at the top of their humanitarian and development agendas. The development community has recognised that the insecurity that persists in the aftermath of armed conflict can impede development efforts and progress toward meeting the Millennium Development Goals and sustainable peace. There is also evidence that insecurity, intensified by the prevalence of small arms and the ex-combatants that possess them, can have a negative impact on the economic and social conditions of countries emerging from conflict (Muggah 2005). At the end of conflict there is often a surge of ex-combatants entering the highly competitive labour market. Many times ex-combatants lack skills, assets, and social networks that enable them to create sustainable livelihoods. As a result, ex-combatants may return to war or a life of criminality and banditry that could adversely affect the peace process. Providing support for ex-combatants is therefore central to any post-conflict reconstruction process. This study will examine how international organisations can best support the reintegration of ex-combatants into society.

In response to the challenge of building human security in post-conflict settings, the international community has instituted a programme most commonly referred to as Disarmament, Demobilisation, and Reintegration (DDR) - three distinct yet overlapping components. Under varying 
nomenclature, DDR programmes are implemented by the United Nations, the World Bank, international and local non-governmental organisations (NGOs) as well as the Organisation for Economic Co-operation and Development (OECD) nations. In his report to the United Nations Security Council (UNSC), Kofi Annan reaffirms, 'the matter of disarmament, demobilization and reintegration of ex-combatants in a peacekeeping environment as part of its continuing effort to contribute to enhancing the effectiveness of United Nations peacekeeping and peace-building activities... has repeatedly proved to be vital to stability in a post-conflict situation; to reducing the likelihood of renewed violence, either because of a relapse into war or outbreaks of banditry; and to facilitating a society's transition from conflict to normalcy and development' (UNSC 2000a:1).

Through processes such as the United Nations' Integrated DDR Standards (IDDRS), the Stockholm Initiative on DDR (SIDDR) and the Multi-donor Reintegration Programme (MDRP), there has been a growing acceptance that DDR, as opposed to simply a military activity, must be treated as a political, social, and economic process that intersects with sustainable long-term development (Bell \& Watson 2006). Whereas disarmament and demobilisation primarily focus on the individual, reintegration shifts from the individual to the community that the ex-combatant is relocating to. In order for DDR programmes to succeed, sufficient resources and planning must be invested in the reintegration phase. It has been shown that in cases where donors have reduced or eliminated funding prematurely during reintegration, ex-combatants have been likely to resort back to lives of violence and crime. If left untreated, ex-combatants may form criminal gangs and militia groups, partaking in crime based on trade in drugs, stolen goods, and illicit weapons (Muggah 2005), as was the case in Angola, in the late 1990s, where reports linked high levels of crime and banditry to the failure of the DDR programme (UNIDIR ${ }^{1} 1999$ ). While all three elements of the DDR process are equally important in restoring peace and security, this paper will primarily focus on reintegration, the longest and most often neglected phase of DDR. The successful

1 United Nations Institute for Disarmament Research 
reintegration of ex-combatants presupposes that there is a community that is socially and economically ready and able to receive them. However, this is often not the case. Having reviewed a wide range of literature explaining the reasons for successful reintegration of ex-combatants (dependent variable), this study will focus on social capital (independent variable) as a causal determinant of successful reintegration. Utilising a thorough literature review of social capital and community-focused reintegration and an in-depth case study of community-based reintegration in Sierra Leone, this study will link social capital with reintegration success. In order to measure success in Sierra Leone, three dependable reintegration evaluations will be used to operationalise the indicators for successful reintegration.

\section{Social capital}

\section{Background}

Social capital is a multidimensional term that has been defined by several social scientists, all pointing to human relationships as a resource or form of capital just as valuable as human and monetary capital. Robert Putnam describes social capital as networks of trust, which are based on agreed upon norms that can enhance efficiency through collaborative action (Putnam 1993). In Francis Fukuyama's seminal work, Trust, he highlights the importance of association and formation of civil society, claiming that it can only take shape in communities with shared norms and values. Out of such shared values, he argues, comes trust, which when mobilised becomes an economic value (Fukuyama 1995).

Social capital is the fabric that creates the bonds necessary for civil and civic society to effectively put policies in place. Strong social capital forms connections that cross ethnic, religious, income, and gender lines, providing a basis for post-conflict mediation, management, and mechanisms for sustaining peace and development. Before liberalising economic and political institutions, it is vital to build horizontal and vertical social capital, so that newly established frameworks will have a dependable base from which to operate. This includes developing an efficient, non-corrupt bureaucracy and 


\section{The Nexus between Social Capital and Reintegration of Ex-combatants}

judiciary, a free press, and a participatory civil society. Social networks are integral features of peacekeeping and fulfil an important role in instituting reconstruction and reconciliation measures in post-conflict states. Countries emerging from conflict with vibrant civil society organisations and networks among its citizens can often regenerate social capital that may have deteriorated during the conflict.

\section{Social capital and armed conflict}

During armed conflict, social capital is often hijacked and used to form allegiances in the warring parties. In other words, combatants join a new social unit that rewards them with social status and a means to earn a living. In some cases, social capital is generated in the formation of demanding the right to economic equality or simply identifying a common enemy. Such was the case in Rwanda, where Hutus used ethnic-based common values to rationalise the massacre of almost 1 million Tutsis (Colletta \& Cullen 2000). It is often difficult for combatants to stop fighting, because the 'war family' (Hazen 2007:1) defines their identity and is a source of security. Moreover, violence contributes to social fragmentation by polarising communities and forcing individuals to take sides during the conflict. Citizens are likely to withdraw from institutions with crosscutting ties, retreating to formal groups based on greater alliances, such as race and religion. This breakdown is important for survival, but has damaging impacts on the economy. For instance, when trust is destroyed, transaction costs rise due to the extra measures that must be taken to ensure proper delivery of goods and services. In addition, tolerance levels decrease and discrimination grows as groups lose the ability to interact outside of their own. ${ }^{2}$

Post-conflict societies that have been involved in human rights abuses and mass killings are often left with low levels of trust and damaged social capital. As for ex-combatants, the DDR process strips them of their social status, their sense of importance, their income, and their support network (Hazen 2007). This is exacerbated by the reluctance of communities to accept the return of ex-combatants, who in many cases had committed atrocities in the very

2 Phone interview with Nat Colletta on December 8, 2006 
communities that they wish to return to. In Uganda, for example, distrust and resentment were widespread during the initial stages of demobilisation and reintegration. Communities were unwilling to accept the return of ex-combatants that had terrorised their lives for so many years. In some cases, this led to hostilities and alienation in the early phase of reintegration (Colletta et al 1996).

In order for ex-combatants to reintegrate, they must relinquish ties with wartime social networks, and reacclimatise themselves with a new social structure, which includes unfamiliar norms, beliefs, and laws within the community. Making this transition can be confusing and psychologically traumatic for ex-combatants and the communities that they return to. Therefore, successful long-term reintegration, as part of the DDR process, can positively impact conflict resolution processes and the rebuilding of social capital (Colletta et al 1996). On the other hand, failure to conduct well planned and funded reintegration programmes can lead to further deterioration in social capital, poor economic conditions, and possibly violence. Reintegration programmes that use existing community organisations enable communities to take ownership of development, while facilitating the reintegration of ex-combatants. Informal networks among ex-combatants, such as discussion groups, veterans' associations, and business ventures are key elements for successful economic and social reintegration. These networks are especially powerful in societies where social capital is scarce (Colletta 1997).

Social capital must be transformed and catalysed so that both ex-combatants and the community can benefit from the many networks of trust that result. It is essential that ex-combatants be fully engaged in the formation of civil society, which is both a by-product and a generator of social capital (Levinger 2005). To achieve this, economic and social reintegration must be embedded in a larger process that addresses ex-combatants within the development framework of their communities. This paper will examine reintegration, claiming that without a community-focused approach that fosters new, and nurtures pre-existing, forms of social capital, ex-combatants will be less likely to secure sustainable livelihoods in post-conflict environments. 


\section{Community-focused reintegration}

As opposed to targeting ex-combatants on an individual level, communityfocused reintegration demands more flexible timetables and funding from donors, and views the reintegration process as a means of equally benefiting ex-combatants and community members. The World Bank estimates that it costs approximately US $\$ 1,200$ to turn an ex-combatant into a civilian, with a job and a role in his or her community (World Bank 2005). This figure does not take into account the need to deliver funds for varying costs based on the needs of ex-combatants vis-à-vis their communities. Reintegration programmes that solely focus funds on the ex-combatant may be neglecting those in the community most affected by conflict. Hence, in the past few years, there has been a pendulum swing from individual to community reintegration. Nat Colletta, formerly of the World Bank, argues that there must be a balance between targeting individual ex-combatants in the shortterm to bring about security and stabilisation and targeting communities in the long-term to encourage identity change, acceptance in the community, and economic integration. ${ }^{3}$ This approach aims to provide a wide range of services for which there is demand to both ex-combatants and community members (USAID 4 2005). DDR programmes that only target ex-combatants have received criticism, claiming that those that have been perpetrators of violence unjustifiably benefit from skills training, and are rewarded with cash packages, while community members are neglected. Although it has been shown that transitional cash payments ultimately benefit the community (Willibald 2006), it is only natural for community members to develop animosity toward ex-combatants when such support is issued. Services to ex-combatants must be offset by programmes that directly benefit communities.

A community approach to reintegration ensures that ex-combatants are given training in skills that suit the demand of the job market. In Mozambique, ex-combatants were unable to find employment in the areas in which they

3 Phone interview with Nat Colletta on December 8, 2006

4 United States Agency for International Development 
were trained. This highlights the need for training programmes to be designed around the needs of the local community and to job opportunities that are realistic. This can be achieved through labour market surveys, demographic assessments of ex-combatants, or by using key informants at the community level (UN 2006). Linking the needs of the community with relevant skills training enables ex-combatants to take steps toward sustainable livelihoods.

\section{BOX 1 - Reintegration Impact Indicators}

- Percentage of ex-combatants the programme has returned to full time education or sustainable productive economic activities.

- Percentage of child ex-combatants the programme has placed into full time education, training, apprenticeship, or income generating activities.

- Level of participation of ex-combatants in community groups, associations, and unions.

- Level of crime among ex-combatants.

- Level of social conflict reported between ex-combatants and civilians.

- Prevalence of the use of the term 'ex-combatant' in the community.

Source: Arthy 2003

DDR programmes can be structured to help communities as well as ex-combatants. For instance, establishing health centres for ex-combatants usually demands that existing health facilities and services be upgraded. With proper coordination and consultation with community leaders, such improvements can benefit community members (UN 2006). Additional reintegration methods that can be employed to nurture social capital are:

- Stopgap programmes

- Media and public awareness campaigns 


\section{The Nexus between Social Capital and Reintegration of Ex-combatants}

- Community development projects

- Programmes for special target groups

- Reconciliation programmes

\section{Stopgap programmes}

Between the demobilisation and reintegration phase, it is sometimes beneficial to undertake stopgap programmes for ex-combatants. These are 2-3 month programmes that pay ex-combatants for demining and for the construction of community infrastructure, such as schools, water systems, hospitals, roads that may have been damaged or destroyed during the war (Caramés 2006). This is a crucial period for ex-combatants, when they often rearm and resort to banditry if their basic needs are not being met. Stopgap programmes can fill this gap, providing short-term employment for ex-combatants, while benefiting the community in the process. These programmes frequently are an entry to reconciliation between ex-combatants and their communities. In some cases, ex-combatants and community members have worked together forging relationships between the two groups. While stopgap programmes can be highly beneficial, they should not replace the main reintegration mechanism. Stopgap programmes certainly contribute to social reintegration and community building, but such programmes rarely build long-term skills and seldom lead to sustainable livelihoods. Therefore, stopgap programmes should not take the place of broader employment initiatives (UN 2006).

\section{Media and public awareness campaigns}

The establishment of social cohesion between ex-combatants and communities is essential to lasting peace. Particularly at the onset of reintegration, relations between ex-combatants and community members are far from normal. Ex-combatants are often perceived as bringing violence or being a burden to the community. Public education and awareness about the war and the return of ex-combatants is a central component of the reintegration process. The dissemination of information in schools, the media, and in communities not only prepares communities for the arrival of ex-combatants, but aids in the reconciliation process as a tool for crisis 
prevention (Douglas et al 2004). Furthermore, campaigns can develop an understanding among stakeholders that DDR's purpose is not to reward ex-combatants, but rather to equip them with skills and provide them with counselling so that they become valuable assets in rebuilding the society toward greater security and peace (UN 2006).

\section{Community development projects}

Community development projects that employ ex-combatants and community members can be very beneficial toward rebuilding trust and starting reconciliation. During these programmes, implementing agencies develop a decision-making body with representatives from community members and ex-combatants. With a focus on future development, project groups can achieve conflict resolution through planning projects as opposed to dwelling on the conflict itself. ${ }^{5}$

The World Bank-assisted Community Reintegration and Development Project in Rwanda best illustrates this approach. The project focuses on reassigning decision-making authority from the organisation to the community level, strengthening partnerships between the local administration and the local population, and building trust and cooperation within and between the local government and the population. The majority of the projects strive to improve food security, strengthen the capacity of farms and businesses, and repair infrastructure. Under the plan, each group is allocated \$240,000 to fund three to five year Community Development Plans (CDP) (World Bank 1999). This participatory approach to development empowers local communities to take ownership of progress toward a peaceful future.

\section{Programmes for special target groups}

Special groups include female, child, disabled, and sick and/or elderly ex-combatants (Specht and the TRESA Team 2006). Until fairly recently, DDR programmes have not taken into consideration the needs of female ex-combatants. In Security Council resolution 1325 of 2000, however, the UN declared the need for all aspects of reintegration to take into consideration

5 Phone interview with Nat Colletta on December 8, 2006 
the gender dimensions of armed conflict and post-conflict reconstruction. Point 13 of the resolution clearly 'encourages all those involved in the planning for disarmament, demobilization and reintegration to consider the different needs of female and male ex-combatants and to take into account the needs of their dependants', and in point 15 the resolution, 'expresses its willingness to ensure that Security Council missions take into account gender considerations and the rights of women, including through consultation with local and international women's groups' (UNSC 2000b).

Women experience conflict differently from men. Time and again women are victims of sexual as well as armed violence. This requires that women receive psychological counselling and support from women's associations within the community. In addition to fighters, women are often used as messengers, cooks and war wives, which are roles that don't always require being armed. Consequently, women are excluded from the DDR programme when they are without a weapon to turn in during the disarmament phase (Harsch 2005). While they may not need to be involved in the early phases of disarmament, it is essential that women are encouraged to participate and are supported through demobilisation and reintegration. Trust and understanding can be accomplished through awareness campaigns in the community that focus on sensitising families and potential employers of the hardships that female ex-combatants experienced during the conflict (UNIFEM6 2004).

In Nicaragua and El Salvador, where females comprised approximately 30 percent of the total combatants, women were excluded from demobilisation and reintegration by their male counterparts. In response, women formed ex-combatant associations to support one another in their reintegration (Watteville 2002). This also gave rise to decision-making power that women so often lose during the DDR process. In Uganda, the Uganda Community Based Association for Child Welfare (UCOBAC)/UNICEF7 project funded groups in the interest of promoting income-generating projects to improve gender relations within the community (Colletta et al 1996). These

6 United Nations Development Fund for Women

7 United Nations Children's Fund 
associations are particularly effective in countries with poor women's rights records.

Special support is also required for former child soldiers. During war, children experience a psychological trauma that differs from that of adult combatants. Their exposure to violence and insecurity has a deep impact on their social and emotional development. Separate protection and rehabilitation programmes are required, especially for girl soldiers who are often denied assistance during demobilisation and reintegration. For child ex-combatants, reintegration should be family- and community-focused, and should aim to reunite children with their families, provide psychosocial care, and afford them with access to education and vocational training (Kingma 1997b).

Reintegration programmes that address the needs of disabled and chronically ill ex-combatants, and those with HIV/AIDS, lower the chance that these groups will be neglected by the community or the health care system (UN 2006). Assistance to these groups demands that resources be channelled to health and counselling services. This not only benefits the community's medical infrastructure, but also creates social bonds between health care providers and ex-combatants.

\section{Reconciliation programmes}

Reconciliation is both a process and a goal that intersects with DDR and the broader post-conflict reconstruction process. Furthermore, it is a process that includes the search for truth, justice, forgiveness and healing, and is rooted in the idea that societies are capable of moving from a 'divided past to a shared future' (IDEA ${ }^{8}$ 2003:12). Reconciliation involves acknowledging past wrongs and grievances in the hope of moving toward attitudinal changes that will eventually pave the way for developing a shared vision of the future, in which people can live harmoniously without returning to conflict (Hamber \& Grainne 2004). Unfortunately, in more cases than not, countries return to conflict. An example of this can be seen in Guatemala's 
return to conflict twice over a 40 year period of civil war (1954-1994). These events resulted in 180,000 deaths, 40,000 disappearances, the devastation of 400 villages, and displacement of over 1 million people (Colletta \& Cullen 2000).

Typically, reconciliation is generated through three institutional practices: war crime tribunals, truth commissions, and peace commissions (Douglas et al 2004). While these methods have proved successful, local processes, such as traditional ceremonies and cleansing rituals, have sometimes proved more effective than formal ones. Community-based processes are more accessible and many times more efficient than state-run methods. By involving communities in utilising local structures, customs and values, differences can be reconciled through a participatory approach that leads to authentic trust between parties (Duthie 2005).

Cleansing rituals played a critical role in reintegrating Mozambique National Resistance (RENAMO) fighters into communities in Mozambique. The healing process consisted of symbolical rituals designed to purify the identity of the individual and reintegrate him or her back into the community (Honwana 1998). In some cases, ex-combatants spent their demobilisation money on gifts to be given to village elders (Kingma 1997b). The capacity for Mozambicans to utilise local instruments for healing and forgiveness is testimony to the importance of home-grown reintegration. With a community-focused approach, formal reintegration programmes can assist in the facilitation of traditional practices.

Following the brutal rule of the Khmer Rouge in Cambodia, institutional reconciliation processes did not take shape. There have been, however, some notable community initiatives. The UNDP-sponsored Cambodia Resettlement and Rehabilitation Programme (CARERE) is one such case. From 1993 to 2000, CARERE contributed to reconciliation by setting up elected village development councils (VDC), which were responsible for overseeing development projects along with strategies to foster community cohesiveness. VDCs offered support to families, religious and local

9 United Nations Development Programme 
organisations by facilitating activities that emphasised ritual and communal understanding. CARERE's area-based approach brought opposing parts of the community together to build on the fragile peace process (UNDP 2001).

\section{Sierra Leone}

\section{Background}

Sierra Leone received independence from Britain in 1961. Beginning with the Margai brothers of the Sierra Leone People's Party (SLPP), the country was ruled by one corrupt leader after another. In 1967, the SLPP lost power to the All People's Congress, which was led by Siaka Stevens, who gained support through his mobilisation of rural communities against wealthy urbanites. During Stevens' seventeen-year rule, power was consolidated into a one-party state, stripping civil society of its role in political life. An economic crisis brought about by political corruption and international economic factors spawned widespread discontent throughout the country. By 1982, Sierra Leone's flourishing diamond and iron industry had been taken over by a group of corrupt firms that funnelled the majority of profits to government leaders and foreign investors (Adebajo 2002).

In 1985, Stevens relinquished power and handed leadership to Joseph Momoh. Under Momoh, the economy continued to decline as well as the diamond business, which had been appropriated by smugglers and corrupt companies.

Amid growing dissatisfaction, a civil war erupted in March 1991, when Revolutionary United Front (RUF) rebels, backed by Liberian rebel leader Charles Taylor, entered southeastern Sierra Leone. Foday Sankoh, leader of the RUF, met Charles Taylor in the late 1980s while undergoing military training in Libya. The two rebel leaders agreed to support one another in overthrowing their respective governments using the diamond mines in Sierra Leone to finance their incursions (International Crisis Group 2007). Charles Taylor was committed to toppling Sierra Leone's government, so 
that they would withdraw troops from the Economic Community of West African States Cease-fire Monitoring Group (ECOMOG) peace operation in Liberia (Ginifer 2005).

In 1997, the Armed Forces Revolutionary Council (AFRC) took control, and later joined forces with the RUF. Their rule was characterised by extensive human rights abuses and dissolution of the rule of law. In 1998 the AFRC/ RUF were driven out by ECOMOG, who reinstated President Kabbah. In 1998, it was estimated that between 60,000 and 80,000 combatants were engaged in fighting - out of a population of about 4.5 million. The total number of deaths from the conflict is unknown, but is most commonly cited at around 50,000 (Ginifer 2005).

On July 7, 1999, Ahmad Tejan Kabbah, President of Sierra Leone, and Foday Sankoh, leader of the RUF, sat down in Lomé, Togo, to sign a peace agreement ending eight years of fighting (Dobbins et al 2005). On October 22, 1999, the Security Council launched the United Nations Mission in Sierra Leone (UNAMSIL) to oversee the peacekeeping mission. With the support of UNAMSIL, the World Bank and the UK's Department for International Development (DFID), the National Committee for Disarmament, Demobilisation and Reintegration (NCDDR), a governmental organisation lead by President Kabbah, was established to spearhead the DDR process in 1998 (Ball et al 2004).

The first few years of the DDR process saw little progress due to outbursts of violence and lack of political will. However by 2002, the DDR programme had succeeded in disarming 72,490 combatants, far exceeding the expected 45,000 . Of the disarmed, 71,043 were demobilised and 56,751 registered with NCDDR (see box 2). Of the 56,751 ex-combatants that applied for demobilisation, 56,127, nearly 100 percent, filed for reintegration assistance (Comninos et al 2002). 
BOX 2 - Sierra Leone DDR Figures

\begin{tabular}{|l|r|}
\hline DDRP's Beneficiaries NCCDR September 2003 & No. Ex-combatants \\
\hline Combatants Disarmed (phases I, II and interim) & 72,490 \\
\hline Ex-combatants demobilised (children included) & 71,043 \\
\hline $\begin{array}{l}\text { Ex-combatants discharged } \\
\text { (by receiving identification cards) }\end{array}$ & 69,463 \\
\hline Child ex-combatants demobilised & 6,845 \\
\hline $\begin{array}{l}\text { Ex-combatants registered to receive reintegration } \\
\text { assistance }\end{array}$ & 48,751 \\
\hline $\begin{array}{l}\text { Ex-combatants having received or receiving } \\
\text { reintegration assistance }\end{array}$ & \\
\hline $\begin{array}{l}\text { Discrepancy between the numbers disarmed, demobilised and } \\
\text { discharged reflects combatants lost during the January 1999 attack } \\
\text { on Freetown and those rearmed and remobilised during the Fall 2000 } \\
\text { security breakdown at the end of Phase Interim. }\end{array}$ \\
\hline
\end{tabular}

Source: Ball et al 2004

\section{Community-focused reintegration}

Social capital eroded during the conflict, damaging support networks and institutional ties. The use and threat of small arms deeply undermined systems of trust and organisational cooperation. In both urban and rural settings, social cohesion was destroyed, which led to divisions and at times robbery among neighbours (Ginifer 2005). With this in mind, NCDDR took a community-centred approach to reintegration. The National Recovery Strategy states that a community approach should be adopted, and that long-term reintegration will only be accomplished by engaging host communities with an equal share of resources afforded to ex-combatants and non-combatants (Sierra Leone National Recovery Strategy 2002).

The NCDDR Training and Employment Programme (TEP) was established to offer ex-combatants options for social and economic reintegration. The main areas of training were in carpentry, car mechanics, tailoring, and agriculture. In addition to training, the programme offered psycho-social 


\section{The Nexus between Social Capital and Reintegration of Ex-combatants}

support and counselling (Comninos et al 2002). NCDDR also encouraged ex-combatants to find work that benefited the community, such as public works, street cleaning, and construction. In addition, education programmes, peace education, music and sports groups have been established to restore social capital (Ginifer 2003).

Stopgap or temporary work programmes proved to be successful for reintegrating ex-combatants. In addition to giving them access to money at a critical time, ex-combatants were able to prove themselves to community members by working side by side with them on community projects. These often broke down social barriers, built confidence, and formed new social ties. This was especially advantageous for ex-combatants who were displaced, unable to rely on families for financial and moral support (Arthy 2003). The UK-backed Community Reintegration Programme (CRP) and the German aid organisation, Deutsche Gesellschaft für Technische Zusammenarbeit (GTZ), played a leading role in community-focused reintegration throughout Sierra Leone. Their projects targeted badly affected communities by setting up employment opportunities and social reintegration programmes for ex-combatants (Ginifer \& Oliver 2004).

In order to sensitise and build trust within the community, NCDDR conducted information dissemination exercises. These were complemented by campaigns in the media and on radio stations countrywide (Ginifer 2003). Religious leaders found it helpful to use radio as a means of reaching out to affected communities. Through a mix of prayer, information, and song, reconciliatory processes were broadcasted throughout the country (Comninos et al 2002). Radio UNAMSIL also played a leading role in addressing issues such as crime, justice, tolerance, forgiveness, and peace (Ginifer 2003).

Many ex-combatants returned to their place of origin to reunite with families. In other cases, ex-combatants were given access to land, which can sometimes lead to disputes over land and past grievances. However, ex-combatants have reported acceptance from neighbours. This is due in part to the establishment of Joint Farms that placed ex-combatants and 
civilians together, working collectively. Once settled, ex-combatants were encouraged to join organised groups centring on themes, such as agriculture, trade, sports, culture (Arthy 2003).

Reintegration was especially difficult for women, who suffered psychological trauma during the conflict. Many women were sexually abused and separated from their families. This was compounded at the onset of reintegration by a myriad of false perceptions by other ex-combatants and community members. Suspicions arose that stigmatised women as being overly violent and having diseases, such as HIV and sexually transmitted diseases (STDs). This soon faded when women had the opportunity to work with others during training. Women that received training often ended up acting as mentors for other war-affected women (Comninos et al 2002). GTZ set up Women's Welfare Committees in all its supported communities to assist women with microcredit and other business opportunities. CRP also established centres in Magboraka and Tonkolili Districts for women to seek counselling (Arthy 2003). Despite these achievements, women were generally neglected by the NCDDR due to their gender-neutral approach, which set DDR registration standards equally for men and women (Ball et al 2004).

Unlike female combatants, child soldiers were placed into a separate programme from the beginning. It is estimated that roughly 7,000 child soldiers were involved in the conflict in Sierra Leone (Ball et al 2004). By 2002, 6,845 child soldiers were demobilised, and the strategy after demobilisation was to reunite child ex-combatants with their families. During reintegration, NCDDR, UNAMSIL, UNICEF as well as other organisations conducted campaigns to sensitise communities to the return of child ex-combatants. Community meetings, posters, and radio were the most common means of informing citizens (Coalition to Stop the Use of Child Soldiers 2006). Former youth combatants have also been well received by youth groups. At times organised by partnering NGOs, youth groups were formed around sports clubs, religious institutions or dance halls. These groups play a vital role in socialising ex-combatants that in many cases lost out on their childhood. Youth groups have also been hired to help 
with minor infrastructure projects such as road maintenance and sanitation (Comninos et al 2002).

The people of Sierra Leone showed a high propensity for reconciliation, based on deep religious faith and fatigue from the war. Local and international NGOs assisted in developing a grassroots movement that ignited reconciliation among differing groups (Ball et al 2004). As in the case of Mozambique, traditional reconciliation techniques, such as cleansing rituals, had a positive impact on communities in Sierra Leone. In addition to male and female ex-combatants, traditional practices were often extended to child ex-combatants. In some cases, ex-combatants received forgiveness from entire communities after admitting wrongdoing (Ginifer 2003). Particularly among the RUF, digging up of 'charms' was a popular ceremony. It is believed that progress in the community cannot be made until charms are dug up and destroyed (Arthy 2003). In tandem with the Truth and Reconciliation Commission, local reconciliation programmes have helped citizens to absolve those that committed horrifying acts, while bridging ties for a shared future.

\section{Measuring success of reintegration}

Experts often cite the case of Sierra Leone as a DDR success story. In addition to the achievement of peace between the warring parties, it is due in large part to the accomplishment of its disarmament and demobilisation process. The large number of weapons collected along with the high percentage of demobilised combatants is indicative of a well-implemented DDR programme. In terms of measuring the success of reintegration, however, many more factors come into play. As opposed to a quantitative assessment of the number of ex-combatants registered for reintegration, analysts must look at qualitative as well as quantitative indicators to measure success. In other words, employment rates can be a reliable indicator pertaining to economic reintegration, whereas social reintegration demands perception indicators to measure levels of cooperation, acceptance, and trust. With additional time and resources, a more thorough analysis and study of reintegration success could be conducted. Nonetheless, given the parameters 
of this study, three reputable analytical studies will be used for measurement purposes.

The NCDDR assessment team, with the support of implementing partners, conducted an evaluation of Sierra Leone's reintegration programme. Findings were obtained through interviews with and surveys to NCDDR staff as well as a sample population of ex-combatants (Comninos et al 2002). An analysis of the following survey results from 2002, when DDR was completed, reflects an interesting dichotomy (See box 3). The first two questions are based on behaviour - quarrels and acceptance. Both findings suggest that ex-combatants reached a level of comfort in their communities in a short amount of time. This suggests that ex-combatants and communities benefited from reintegration programmes that aimed at sensitisation and normalisation. The third question, regarding trust, reveals that by 2002, ex-combatants had not gained a high level of trust in relation to neighbours, friends, and particularly family. Further analysis may explore the reasons behind the majority of ex-combatants distrusting family over friends and neighbours. It would also be useful to know whether high levels of trust existed prior to the conflict. In all, this survey illustrates that reconciliation and the establishment of social capital is a process that takes time and must not be ignored during DDR, and principally when these programmes end.

BOX 3 - Assimilation in Communities

\begin{tabular}{|l|c|c|c|c|c|c|}
\hline $\begin{array}{l}\text { Do you quarrel } \\
\text { with... }\end{array}$ & Family & Friends & Neighbours & $\begin{array}{c}\text { Colleagues } \\
\text { at Work }\end{array}$ & Strangers & $\begin{array}{c}\text { People in } \\
\text { Authority }\end{array}$ \\
\hline Yes, all the time & $1.8 \%$ & $0.8 \%$ & $1.0 \%$ & $0.5 \%$ & $0.5 \%$ & $1.3 \%$ \\
\hline $\begin{array}{l}\text { Yes, } \\
\text { but only sometimes }\end{array}$ & $22.0 \%$ & $30.8 \%$ & $17.5 \%$ & $15.0 \%$ & $3.5 \%$ & $4.5 \%$ \\
\hline No, never & $76.3 \%$ & $68.5 \%$ & $81.5 \%$ & $84.5 \%$ & $96.0 \%$ & $94.3 \%$ \\
\hline Total & $100.0 \%$ & $100.0 \%$ & $100.0 \%$ & $100.0 \%$ & $100.0 \%$ & $100.0 \%$ \\
\hline $\mathrm{n}=$ & & &
\end{tabular}




\begin{tabular}{|l|c|c|c|}
\hline Problems being accepted by... & Family & Friends & Neighbours \\
\hline Yes regular problems & $0.8 \%$ & $0.3 \%$ & $0.8 \%$ \\
\hline Yes occasional problems & $3.0 \%$ & $3.3 \%$ & $3.3 \%$ \\
\hline No problems & $96.3 \%$ & $96.5 \%$ & $96.0 \%$ \\
\hline Total & $100.0 \%$ & $100.0 \%$ & $100.0 \%$ \\
\hline n= & & \multicolumn{2}{|c|}{40} \\
\hline Do you trust your.... & Family & Friends & Neighbours \\
\hline Yes I trust them all the time & $14.0 \%$ & $7.5 \%$ & $6.5 \%$ \\
\hline Yes I trust them, but only occasionally & $7.8 \%$ & $30.0 \%$ & $27.8 \%$ \\
\hline No I do not trust them & $78.3 \%$ & $62.5 \%$ & $65.8 \%$ \\
\hline Total & $100.0 \%$ & $100.0 \%$ & $100.0 \%$ \\
\hline & & & \\
\hline
\end{tabular}

In 2003, DFID conducted an impact evaluation of their reintegration programmes, which were implemented by GTZ and CRP. Through interviews (total 27), focus group discussions (total of 30 with 10 representatives at each), and participatory workshops with programme staff, DFID found that community perceptions had shifted from one of suspicion and distrust to one of cooperation and peaceful coexistence. Indicative of this was the absence of the term 'ex-combatant' in everyday conversation. Community members expressed the desire to move on from 
past grievances, recociling differences to form cohesive communities. The majority of commnity members reported that relations with ex-combatants improved significantly from their first contact during demobilisation to the end of reintegration. Consistent with community respondents, ex-combatants expressed an absence of problems between the two parties (Arthy 2003). This evaluation reveals that relations between ex-combatants and their communities are such that an enabling environment has been established for economic and social development. Whether these conditions can be fully attributed to reintegration is nebulous and difficult to measure. Nevertheless, it is safe to assume that reintegration programmes contributed to other community processes that may have been taking place.

Between June and August 2003, just more than a year after the conflict subsided, Humphreys and Weinstein conducted a study targeting a sample of 1,043 ex-combatants. Information was gathered through closed-ended questionnaires and interviews at training sites and in community centres. In order to obtain a representative sample it was disaggregated by region, gender, faction, and age. $89 \%$ of their sample joined the DDR programme, while $11 \%$ chose to reintegrate on their own. This ratio is consistent with the figure that states 7,000 out of the total 79,000 combatants did not join the DDR programme countrywide. According to their measure of successful reintegration, $93 \%$ of the respondents experienced high levels of reintegration success, $2 \%$ cluster at the very bottom, and $5 \%$ are dispersed around the middle (Humphreys \& Weinstein 2004). While 7\% seems to be an insignificant number, it represents 5,000 ex-combatants that expressed mild to extreme levels of dissatisfaction with reintegration. Examining the experience of these 5,000 ex-combatants may reveal some interesting insights and lessons for future DDR programmes. 
BOX 4 - Ex-combatants' Perspective on Training

\begin{tabular}{|l|c|c|c|c|}
\hline & Agree (\%) & Disagree (\%) & Neither (\%) & \# of Respondents \\
\hline $\begin{array}{l}\text { The training } \\
\text { I received has } \\
\text { prepared me well } \\
\text { for my work. }\end{array}$ & 75.8 & 19.2 & 5.0 & 318 \\
\hline $\begin{array}{l}\text { The skills I learned } \\
\text { are needed by } \\
\text { employees in this } \\
\text { region. }\end{array}$ & 91.5 & 4.7 & 3.8 & 339 \\
\hline $\begin{array}{l}\text { I am better socially } \\
\text { because of the } \\
\text { training I received }\end{array}$ & 87.1 & 7.1 & 5.9 & 340 \\
\hline $\begin{array}{l}\text { The training } \\
\text { I received was } \\
\text { responsible for the } \\
\text { job I have. }\end{array}$ & 42.9 & 51.6 & 5.5 & 219 \\
\hline
\end{tabular}

Source: Humphreys \& Weinstein 2004

The results (in percentages) from box 4 above demonstrate that training was mostly perceived to be helpful. With regard to preparation for work, demand of skills, and social benefits, ex-combatants responded positively. Interestingly, responses were mixed when asked about post-training employment. There are a number of economic factors that may have contributed to this result.

Ex-combatants' perspective on employment opportunities was not as favourable (See box 5). More than 50\% of the respondents thought opportunities were the same or worse than before the war. These results 
were especially poor for the SLA ${ }^{10}$ and the AFRC, who compared with the militias, lost more in terms of job security and social status. This result raises a good question regarding programme expectations. Does arriving at these employment results one year after the programme constitute failure? There are a number of externalities beyond the control of the reintegration programme that can affect this indicator. By isolating perceptions of employment opportunities, factors related to economic degradation from war and possible post-conflict reconstruction failures might be disregarded. Further studies may want to consider proposing benchmarks for employment opportunities following reintegration. This would be extremely challenging due to the complexities and variables that each post-conflict context contains.

\section{BOX 5 - Employment Opportunities}
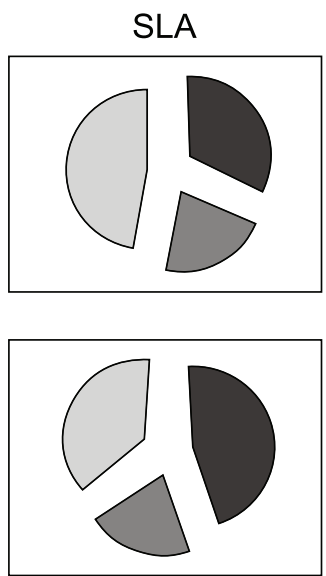

CDF
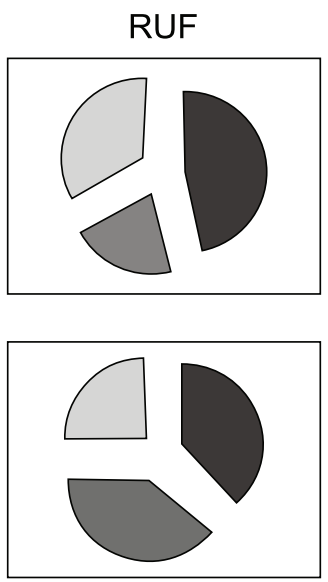

WSB

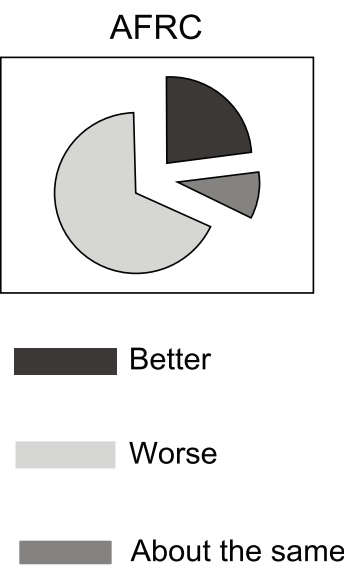

About the same

Source: Humphreys \& Weinstein 2004

10 Sierra Leone Army 


\section{The Nexus between Social Capital and Reintegration of Ex-combatants}

\section{Conclusion}

Along with the increase of involvement of the international community in post-conflict assistance, has come a greater focus on DDR. It has been well established that DDR is an essential component of post-conflict recovery. While development and humanitarian organisations focus on improving political and economic institutions and upholding the peace, particular attention must be paid to ex-combatants, who are most prone to become spoilers of the peace process. Given their access to weaponry, their experience with armed violence, and left-over animosity, ex-combatants are most likely to return to violence if conditions do not allow them to make the transition from war to peace. In post-conflict settings, economies and institutions are too damaged and fragile to absorb tens to hundreds of thousands of ex-combatants at once. Therefore, it is imperative that wellplanned and dynamically funded DDR programmes are implemented.

While disarmament and demobilisation are important, it is the reintegration phase that requires the greatest amounts of time and funding for successfully assisting ex-combatants and their return to sustainable livelihoods in their former or sometimes new communities. Typically, reintegration targets the individual ex-combatant with cash packages and job training. More recently, there has been a shift in conventional wisdom, calling for a community-focused approach to reintegration. Consequently, this study argues that both individual and community-based reintegration approaches are important when conducting DDR programmes.

In addition to human and financial capital, social capital must be cherished and nurtured in post-conflict settings. As a measure of trust and reciprocity, social capital is the driving force behind reconciliation and normalisation processes. This study attempts to show that communityfocused reintegration programmes that generate social capital will build networks of trust and cooperation through the community for which ex-combatants can rely on for a safe and sustainable return. Likewise, community members are able to relinquish past grievances, while focusing on progress and a shared vision of peace. Reintegration programmes that 
provide its beneficiaries with an atmosphere conducive to cooperative organisation building, leads to an empowered civil society with the capacity to recycle social capital for its own benefit indefinitely.

In order to illustrate the relationship between community-based reintegration programmes that promote social capital and the extent to which ex-combatants successfully reintegrate, this study examined the experience of Sierra Leone. As a current model, Sierra Leone reveals the advantages that a community-focused reintegration approach bequeaths to its recipients. While reintegration results are mixed for some indicators, there are, however measurable lessons that can be taken from the reintegration methodologies that were instituted there. Programmatic interventions that proved successful in Sierra Leone can be duplicated in future DDR scenarios, and will most likely have positive impacts if tailored to the post-conflict context in which they are applied.To build on the lessons learned from Sierra Leone, the following policy recommendations should be considered by current and future DDR implementing actors:A global fund should be established for long-term reintegration of ex-combatants. This would comprise a group of experts that could assess post-conflict reconstruction in relation to the needs of ex-combatants and their communities, reducing reliance on voluntary contributions of UN member states.

1. Donors should incorporate longer-term reintegration packages that support community-based organisations engaged in assisting ex-combatants and their communities. Reintegration shall be outlined during the peace process with a designation of implementing organisations and funding bodies. Once disarmament and demobilisation are complete, funding should not be curtailed, but rather enhanced to ensure long-term recovery.

2. Instead of viewing reintegration as the third stage of DDR, reintegration should be perceived as a much broader process that begins at the onset of DDR. 


\section{The Nexus between Social Capital and Reintegration of Ex-combatants}

3. Coordination among the government, NGOs, community organisations, and donors should take place as early as possible to avoid duplication of efforts, regional favouritism, and loss of confidence within communities.

4. Social capital should not only be nurtured during all stages of DDR, but should also be an objective of the entire programme. Social capital should be strengthened by utilising existing community organisations, which enables communities to take ownership of their own development and reintegration of ex-combatants. Community programmes should be participatory, equitable, and sustainable, so that recipients can benefit from the programme long after completion.

5. DDR programme managers should encourage the establishment of informal networks of ex-combatants, which serve as a platform for discussion between them and their communities.

6. Implementing actors must conduct participatory monitoring and evaluation of programmes that take into account the need of all stakeholders. This gives ex-combatants and community members a sense of ownership that leads to cooperation and acceptance.

The findings of this study suggest that reintegration programmes that address both the needs of the individual ex-combatant and communities with proper funding in a timely manner will reduce the risk that ex-combatants will turn to lives of criminality once released from their role as combatants. In a world where armed conflict persists, international organisations should not underestimate or take for granted the transformative effects that social capital has on rebuilding communities. By placing programmes that enhance social capital at the top of the post-conflict agenda, citizens will become empowered to take control of their future aspirations for economic development, political stability, and peace. 


\section{Sources}

Adebajo, Adekeye 2002. Building Peace in West Africa. Boulder \& London: Lynne Rienner Publishers.

Arthy, Simon 2003. DFID Funded Reintegration Activities in Sierra Leone: Reintegration Lesson Learning Impact Evaluation. DFID.

Ball, N., Nenon, J. \& Tesfamichael, G. 2004. The Final Evaluation of Disarmament, Demobilization and Reintegration Program and the Multi-Donor Trust Funds Supporting $D D R$. Washington, DC: Creative Associates International Inc.

Bell, Edward \& Watson, Charlotte 2006. DDR: Supporting Security and Development. International Alert. London.

Caramés, Albert 2006. Community Reintegration. Escola De Cultura De Pau. Available at: $<$ http://www.pangea.org/unescopau/english/programas/desarme.htm>

Coalition to Stop the Use of Child Soldiers 2006. Child soldiers and Disarmament, Demobilization, Rehabilitation and Reintegration in West Africa. Available at: <http:// www.child-soldiers.org/resources/Nov_2006_-WestAfrica_Surveydoc_-_FINAL.pdf>

Colletta, N., Kostner, M. \& Wiederhofer, I. 1996. Case Studies in War to Peace Transition: the Demobilization and Reintegration of Ex-Combatants in Ethiopia, Namibia, and Uganda. Washington, DC: World Bank.

Colletta, Nat 1997. Demilitarization, Demobilization, and the Social and Economic Integration of Ex-combatants: Lessons from the World Bank of Africa. USAID Conference Promoting Democracy, Human Rights, and Reintegration in Post-conflict Societies, October 30-31, 1997. Available at: <http://pdf.dec.org/pdf_docs/PNACD087. pdf>

Colletta, N. \& Cullen, M. 2000. Violent Conflict and the Transformation of Social Capital. Washington, DC: The World Bank.

Comninos, S., Stavrou, A. \& Stewart, B. 2002. Draft Assessment of the Reintegration Programmes of the National Committee for Disarmament, Demobilization and Reintegration. Freetown: Sierra Leone.

Dobbins, J., Jones, S., Crane, K., Rathmell, A., Steele, B., Teltschik, R. \& Timilsina, A. 2005. The UN's Role in Nation-Building: From the Congo To Iraq. Santa Monica: The Rand Corporation.

Douglas, I., Gleichmann, C., Oderwald, M., Steenken, K. \& Wilkinson, A. 2004. Disarmament, Demobilization and Reintegration: A Practical Field and Classroom Guide. Frankfurt: GTZ.

Duthie, Roger 2005. Transitional Justice and Social Reintegration. Stockholm Initiative on Disarmament Demobilization Reintegration (SIDDR). Available at: $<$ http://www. sweden.gov.se/content/1/c6/06/54/ 02/7545e870.pdf>

Fukuyama, Francis 1995. Trust. New York: The Free Press.

Ginifer, Jeremy 2003. Sierra Leone - Building the Road to Recovery. ISS Monograph Series No. 80. Pretoria: Institute for Security Studies (ISS). Available at: $<$ http://www.iss.co.za/ Pubs/Monographs/ No80/Chap2.html> 


\section{The Nexus between Social Capital and Reintegration of Ex-combatants}

Ginifer, J., \& Oliver, K. 2004. Evaluation of the Conflict prevention Pools. Department for International Development (DFID).

Ginifer, Jeremy 2005. Armed Violence and Poverty in Sierra Leone: A Case Study for the Armed Violence and Poverty Initiative. Bradford: Centre for International Cooperation \& Security, University of Bradford.Availableat: < http://www.smallarmssurvey.org/files/portal/spotlight/ country/afr_pdf/africa-sierraleone-2005.pdf >

Hamber, B., \& Grainne, K. 2004. Reconciliation: A Working Definition. Available at: <http://cain.ulst.ac.uk/dd/papers/dd04recondef.pdf >

Harsch, Ernest. October 2005. Women: Africa's Ignored Combatants. Africa Renewal, Vol. 19 \#3. Available at: <http://www.un.org/ecosocdev/geninfo/afrec/vol19no3/193 women.html>

Hazen, Jennifer 2007. Social Integration of Ex-Combatants after Civil War. Available at: $<$ http://www.un.org/esa/socdev/egm/paper/Jennifer\%20Hazen.pdf>

Honwana, Alcinda 1998. Sealing the past, facing the future: trauma healing in rural Mozambique. Conciliation Resources. Available at: <http://www.c-r.org/our-work/ accord/mozambique/past-future.php>

Humphreys, M., \& Weinstein, J. 2004. What the Fighters Say: A Survey of Ex-combatants in Sierra Leone. Columbia University, Stanford University, and The Post-conflict Reintegration Initiative for Development and Employment (PRIDE). Available at: $<$ http://www.columbia.edu/ mh2245/Report1_BW.pdf $>$

IDEA (International Institute for Democracy and Electoral Assistance) 2003. Reconciliation After Violent Conflict: A Handbook. Stockholm: International Idea. Available at: $<$ http:// www.idea.int/publications/reconciliation/upload/reconciliation_full.pdf >

International Crisis Group 2007. Conflict History: Sierra Leone. Available at: $<$ http://www. crisisgroup.org/home/index.cfm?action=conflict_search\&l=1\&t=1\&c_country=96>

Kingma, Kees 1997a. Demobilization of Combatants After Civil Wars in Africa and Their Reintegration into Civilian Life. Policy Sciences 30: 151-165. Netherlands: Kluwer Academic Publishers.

Kingma, Kees 1997b. Post-war Demobilization and the Reintegration of Ex-combatants into Civilian Life. USAID Conference Promoting Democracy, Human Rights, and Reintegration in Post-conflict Societies October 30-31 1997.

Levinger, Beryl 2005. Civil Society and Social Capital: An Introduction. Powerpoint presentation. November 2005.

Muggah, Robert 2005. No Magic Bullet: A Critical Perspective on Disarmament, Demobilization and Reintegration (DDR) and Weapons Reduction in Post-Conflict Contexts. Commonwealth Journal of International Affairs.

Putnam, Robert 1993. Making Democracy Work. New Jersey: Princeton University Press.

Sierra Leone National Recovery Strategy 2002. Available at: <http://www.sierra-leone.org/ recoverystrategy-iii.html\#3>

Specht, Irma and the TRESA Team 2006. Reintegration Strategies for Ex-Combatants. Training and Education on Small Arms (TRESA). Bonn: Bonn International Centre for Conversion (BICC). 
UN (United Nations) 2006. Integrated Disarmament, Demobilization, and Reintegration Standards (IDDRS).

UNDP (United Nations Development Programme) 2001. UNDP in Cambodia: A Case Study of the CARERE Programme 1991-2000. Phnom Penh: UNDP/Cambodia. Available at: <http://siteresources.worldbank.org/INTCPR/9467341115629527393/20 482565/ CambodiaCARERE.pdf>

UNIDIR (United Nations Institute for Disarmament Research) 1999. The Management of Arms in Conflict Resolution Process. Geneva: UNIDIR.

UNIFEM (United Nations Development Fund for Women) 2004. Getting it Right, Doing it Right: Gender and Disarmament, Demobilization and Reintegration. New York: UNIFEM. Available at: < http://www.womenwarpeace.org/issues/ddr/gettingitright.pdf>

UNSC (United Nations Security Council) 2000a. Report of the Secretary-General: The Role of United Nations Peacekeeping in Disarmament, Demobilization, and Reintegration. S/2000/101 of 11 February.

UNSC (United Nations Security Council) 2000b. Resolution 1325. S/RES/1325.

USAID (United States Agency for International Development) 2005. Community-Focused Reintegration. Available at: < http://pdf.dec.org/pdf_docs/PNADF305.pdf>

Watteville, Nathalie 2002. Addressing Gender issues in Demobilization and Reintegration Programs. The World Bank. Available at: <http://www.womenwarpeace.org/issues/ ddr/DDRWatteville.pdf>

Willibald, Sigrid 2006. Does Money Work? Cash Transfers to Ex-combatants in Disarmament, Demobilization, and Reintegration Processes. Overseas Development Institute. Oxford: Blackwell Publishing.

World Bank 1999 (22 July). Community Reintegration and Development Project Rwanda. Available at: $<$ http://web.worldbank.org/external/projects/main?pagePK=64312881\&piP $\mathrm{K}=64302848 \&$ theSitePK=40941\&Projectid $=\mathrm{P} 051931>$

World Bank 2005 (29 August). From Combatant to Civilian. Available at: <http://web. worldbank.org/WBSITE/EXTERNAL/NEWS/0,contentMDK:20629793 pagePK:6425 7043 piPK:437376 theSitePK:4607,00> 